\title{
Human genome comparison of paretic and nonparetic vastus lateralis muscle in patients with hemiparetic stroke
}

\author{
Michael J. McKenzie, PhD, CSCS; ${ }^{1}$ Shuzhen Yu, MD; ${ }^{2}$ Richard F. Macko, MD; ${ }^{1-3}$ John C. McLenithan, PhD; $^{4}$ \\ Charlene E. Hafer-Macko, MD ${ }^{1-3^{*}}$ \\ ${ }^{1}$ Division of Gerontology, University of Maryland School of Medicine, and Baltimore Geriatric Research, Education, \\ and Clinical Center, Department of Veterans Affairs (VA) Maryland Health Care System, Baltimore, MD; ${ }^{2}$ Department \\ of Neurology, University of Maryland School of Medicine, Baltimore, MD; ${ }^{3}$ Department of Neurology, VA Maryland \\ Health Care System, Baltimore, MD; ${ }^{4}$ Division of Endocrinology, Diabetes, and Nutrition, University of Maryland \\ School of Medicine, Baltimore, MD
}

\begin{abstract}
Hemiparetic stroke leads to major skeletal muscle abnormalities, as illustrated by paretic leg atrophy, weakness, and spasticity. Furthermore, the hemiparetic limb muscle shifts to a fast-twitch muscle fiber phenotype with anaerobic metabolism. This study investigated whether skeletal muscle genes were altered in chronic hemiparetic stroke. The nonparetic leg muscle served as an internal control. We used Affymetrix microarray analysis to survey gene expression differences between paretic and nonparetic vastus lateralis muscle punch biopsies from 10 subjects with chronic hemiparetic stroke. Stroke latency was greater than 6 months. We found that 116 genes were significantly altered between the paretic and nonparetic vastus lateralis muscles. These gene differences were consistent with reported differences after stroke in areas such as injury and inflammation markers, the myosin heavy chain profile, and high prevalence of impaired glucose tolerance and type 2 diabetes. Furthermore, while many other families of genes were altered, the gene families with the most genes altered included inflammation, cell cycle regulation, signal transduction, metabolism, and muscle contractile protein genes. This study is an early step toward identification of specific gene regulatory pathways that might lead to these differences, propagate disability, and increase vascular disease risk.
\end{abstract}

Key words: cell cycle, gene expression, hemiparetic stroke, inflammation, metabolism, microarray, muscle contraction, rehabilitation, skeletal muscle, transcription factors, vastus lateralis.

\section{INTRODUCTION}

Stroke is a leading cause of disability in the United States. More than two-thirds of stroke survivors have chronic functional deficits [1]. Hemiparesis is the most common neurological sequela. Skeletal muscle has recently been recognized as a site of secondary biological change after stroke that may propagate the functional decline and contribute to the increased risk of insulin resistance, cardiovascular disease, and recurrent stroke [2-7]. A number of pathophysiological mechanisms underlie

\footnotetext{
Abbreviations: DNA = deoxyribonucleic acid, $\mathrm{G}_{1}=$ Gap 1, $\mathrm{MHC}=$ myosin heavy chain, $\mathrm{MLC}=$ myosin light chain, $\mathrm{MYH}=$ myosin heavy polypeptide, NIA = National Institute on Aging, $\mathrm{RNA}=$ ribonucleic acid, $\mathrm{S}=$ Synthesis, $\mathrm{SCI}=$ spinal cord injury, SEM = standard error of the mean, SF-36 = 36-item Short Form (Health Survey), SSWS = self-selected walking speed, TNF- $\alpha=$ tumor necrosis factor- $\alpha$, VA $=$ Department of Veterans Affairs, $\mathrm{VL}=$ vastus lateralis, $\mathrm{VO}_{2}=$ oxygen consumption.

* Address all correspondence to Charlene E. Hafer-Macko, MD; VA Maryland Health Care System, GRECC (BT/GR/ 18), 10 North Greene Street, Baltimore, MD 21201; 410-6057000, ext 5413; fax: 410-605-7913.

Email: cmacko@grecc.umaryland.edu

DOI: 10.1682/JRRD.2007.02.0036
} 
the biological changes in muscle in stroke survivors. Stroke alters the motor neuron activation of muscles on the paretic side. After stroke, individuals have a more sedentary lifestyle and an altered gait pattern with reduced weight bearing, which also affect the skeletal muscle. Alterations in skeletal muscle are pronounced on the hemiparetic side after stroke and include gross muscular atrophy, increased intramuscular fat, and a shift to a fast myosin heavy chain (MHC) phenotype with reduced muscle oxidative capacity [8-11]. These muscle abnormalities after stroke have clear implications, since fasttwitch muscle fibers are more fatigable and have anaerobic metabolism [12]. The loss of slow-twitch fibers that take up glucose in response to insulin is relevant to the high prevalence of insulin resistance in stroke survivors [13]. In addition, expression of tumor necrosis factor alpha (TNF- $\alpha$ ), an inflammatory cytokine, is elevated in the hemiparetic leg muscle compared with the nonparetic leg muscle [14]. Whether broader inflammatory pathway activation is present with subsequent downstream impact on muscle cell cycle, protein synthesis, or metabolic function is unknown.

The molecular mechanisms responsible for muscle atrophy, phenotype shift, and altered metabolism after stroke are not known. Stroke subjects offer an interesting perspective for studying the biological changes in hemiparetic muscle, since each subject's nonparetic leg muscle serves as his or her own internal control. The use of bilateral muscle samples eliminates individual genetic variation, which is a considerable limitation of microarray analysis of human tissues. The vastus lateralis (VL) muscle was chosen since all our subjects with hemiparetic stroke have quadriceps weakness and the majority have evidence of spasticity of knee extension. Furthermore, the quadriceps muscle is traditionally examined in studies of aging, diabetes, and exercise interventions [14-15]. This study used Affymetrix deoxyribonucleic acid (DNA) microarray analysis to investigate global gene expression changes underlying the biological changes of muscle structure and metabolic function in paretic and nonparetic VL muscle from subjects with chronic stroke.

\section{METHODS}

Men and women $(n=10) 50$ to 80 years old with residual mild-moderate hemiparetic gait from an ischemic stroke ( $>6$ months poststroke onset, range 7-156 months poststroke) participated in this study of altered skeletal muscle gene expression after stroke. A mild-moderate hemiparetic gait was defined by a clear gait asymmetry with preserved ability to ambulate with or without an assistive device, such as a cane, walker, or ankle-foot orthosis. All conventional rehabilitation therapy was completed more than 12 weeks before study entry, and neurological deficits were stable for more than 8 weeks.

The chronic phase of stroke was selected to ensure stability of the residual hemiparetic gait deficits and avoid any potential confounders of early neurological recovery or intercurrent rehabilitation therapy on skeletal muscle structure and function. Furthermore, the chronic stroke phase was chosen because in spinal cord injury (SCI), another upper motor neuron disorder, alterations in skeletal muscle contractile proteins have been shown to progress over many months after injury [16].

From the larger chronic stroke population participating in our rehabilitation programs $(N=72)$, we randomly selected 10 participants who had given consent for bilateral VL muscle biopsies. Exclusion criteria included medical conditions that limited mobility and participation in exercise programs, recent ( $<3$ weeks) infection or inflammation, anti-inflammatory medications, anticoagulation, or known muscle disease. Individuals provided written informed consent. For each subject, we administered a comprehensive medical history, routine medical and neurological examinations, and questionnaires to estimate stroke disease burden. Cardiovascular fitness levels (peak oxygen consumption $\left[\mathrm{VO}_{2}\right]$ levels) were measured by open-circuit spirometry [17]. Functional and mobility testing included home and community ambulatory activity recorded by a diary and a computerized step activity monitor for 48 hours and the mean of three 10-meter walks that used self-selected walking speed (SSWS) as an index of gait deficit severity [17-18]. Individuals were categorized as having normal glucose tolerance, impaired glucose tolerance, or type 2 diabetes mellitus according to medical history and prescribed medications, fasting glucose levels, and an oral glucose tolerance test (in nondiabetic participants). The University of Maryland Institutional Review Board approved all aspects of this study.

Bilateral VL muscle biopsies were obtained under local anesthesia with a $5 \mathrm{~mm}$ Bergström needle (StilleWerner; St. Paul, Minnesota). VL samples were immediately frozen in liquid nitrogen and stored in a $-80{ }^{\circ} \mathrm{C}$ freezer until assay. We isolated total ribonucleic acid 
(RNA) from VL muscle with TRIzol ${ }^{\circledR}$ Reagent (Invitrogen; Carlsbad, California, catalog number 15596-026) using previously described methods [19]. The RNA was further purified with Qiagen's RNeasy Mini Kit and RNase-free DNase Set (Valencia, California, catalog numbers 74104 and 79254, respectively) according to the manufacturer's instructions. RNA purity and integrity were determined by the A260/A280 ratio and 28S/18S ratio, respectively. Purified RNA was provided to Gene Logic (Gaithersburg, Maryland), where purity and integrity were reverified by the A260/A280 ratio as well as analysis by an Agilent Bioanalyzer (Palo Alto, California, part number 5067-1511). RNA that was deemed pure was hybridized to the Affymetrix Human Genome U133 Plus 2.0 Array (Santa Clara, California, part number 900470) and differential gene expression was analyzed with Gene Logic software.

Statistical analysis was performed with Genesis Enterprise System ${ }^{\circledR}$ software (Gene Logic). This analysis created an $F$-score for each gene measured to determine significance $(p<0.05)$. For a gene to be considered significantly different between the paretic and nonparetic VL muscles, a minimum of 8 of the 10 patients in the study had to unidirectionally differentially express a difference for the gene of interest. Additionally, only genes that had expression differences of at least +1.5 -fold between the paretic and nonparetic VL muscle samples were reported.

\section{RESULTS}

Subject descriptive data are presented in the Table. Participant age ranged from 50 to 80 years. The mean \pm standard error of the mean (SEM) stroke onset latency was $59.1 \pm 18.0$ months. Seven individuals required a single point cane, two required a quad cane, none required a walker, and four required an ankle-foot orthosis. The subjects' SSWSs for the timed 30-meter walks with their usual assistive devices were slow (mean \pm SEM $0.51 \pm 0.10 \mathrm{~m} / \mathrm{s}$, range $0.45-2.34 \mathrm{~m} / \mathrm{s}$ ). Furthermore, cardiovascular fitness levels (peak $\mathrm{VO}_{2}$ ) were significantly reduced in this population (mean \pm SEM $13.7 \pm$ $1.3 \mathrm{~mL} / \mathrm{kg} / \mathrm{min}$, range $9.1-19.0 \mathrm{~mL} / \mathrm{kg} / \mathrm{min}$ ). This functional data for stroke participants demonstrated how the disability of stroke affected their activities and performance, such as walking speed and fitness level. We administered the 36-item Short Form (SF-36) Health Sur- vey to all participants to estimate their perception of disease burden. The participants' mean \pm SEM SF-36 Health Survey physical health score was $50 \pm 4.7$ and mental health score was $76 \pm 2.9$. For the subset of eligible individuals who gave consent for this muscle biopsy study, no significant clinical (peak $\mathrm{VO}_{2}$, walking speed, activity level) or demographic (age, sex, body mass index) differences were found compared with the larger cohort of individuals with chronic stroke participating in our exercise and rehabilitation programs. The Table includes demographic and clinical data demonstrating that the random population selected for muscle biopsies was the "same" as our overall stroke cohort population.

RNA from all subjects was deemed pure as evidenced by an optical density ratio higher than 1.8. This ratio was confirmed by Gene Logic, as well. The RNA concentrations did not differ between paretic and nonparetic VL muscle (all values are presented as mean \pm SEM unless otherwise noted). The RNA concentration was $803.5 \pm 22 \mu \mathrm{g} / \mathrm{mL}$ for the paretic VL and $911.8 \pm$ $45 \mu \mathrm{g} / \mathrm{mL}$ for the nonparetic VL. In this experiment, 116 genes were significantly altered between paretic and nonparetic VL muscle. The Appendix contains a list of identifiable genes significantly altered; genes are shown grouped by function (available online only at http:// www.rehab.research.va.gov). The genes with differential expression included genes related to inflammation, cell cycle regulation, mitogenesis, signal transduction pathways, metabolism, and muscle contractile proteins.

\section{DISCUSSION AND CONCLUSIONS}

This is the first known study to directly examine global gene transcript levels after a hemiparetic stroke. The major finding of this study is the identification of gene expression differences between the paretic and nonparetic VL muscles in chronic stroke survivors. We found substantial interlimb differences in a number of key molecular pathways that likely influence the fundamental structure, metabolism, performance, and regenerative potential of skeletal muscle tissue after stroke. Figure 1 illustrates several pathophysiological factors that could contribute to the biological alterations in skeletal muscle after stroke. These factors include the abnormal neural activation of the paretic limb that causes weakness and spasticity after the stroke, relative disuse and deconditioning, and aging. An understanding of how stroke alters skeletal 
Table.

Data for all subjects participating in larger hemiparetic stroke exercise study and for random subset of subjects who also consented to vastus lateralis (VL) biopsy. Spasticity was measured with modified Ashworth scale. Numbers (0/1/2/3) for spasticity represent number of subjects with spasticity ratings of 0 (normal), 1 (mild increase in tone), 2 (marked increased tone but able to move limb easily), or 3 (passive limb movement difficult because of increased tone). Steps were recorded for 48 hours with computerized step activity monitor (SAM). Self-selected walking speed (SWSS) was determined by timed 10-meter walk. Impaired glucose tolerance or type 2 diabetes mellitus was defined by known diabetes in medical history or medication profile, fasting glucose level, and 2-hour oral glucose tolerance test. Data presented as mean \pm standard error of the mean unless otherwise noted.

\begin{tabular}{|c|c|c|}
\hline Characteristic & $\begin{array}{l}\text { VL Gene Array Study } \\
\qquad(n=10)\end{array}$ & $\begin{array}{l}\text { Hemiparetic Stroke Exercise Study } \\
\qquad(N=72)\end{array}$ \\
\hline$\overline{\text { Age (yr) }}$ & $63.8 \pm 2.9$ & $63.6 \pm 1.1$ \\
\hline Male (\%) & 50 & 46 \\
\hline Left-Hemisphere Stroke (\%) & 40 & 50 \\
\hline Spasticity Rating 0/1/2/3 (No.) & $5 / 3 / 1 / 1$ & $35 / 20 / 14 / 3$ \\
\hline SAM (steps/48 h) & $4,335 \pm 723$ & $4,038 \pm 362$ \\
\hline SSWS $(\mathrm{m} / \mathrm{s})$ & $0.51 \pm 0.10$ & $0.52 \pm 0.03$ \\
\hline Impaired Glucose Tolerance or Diabetes (\%) & 70 & 70 \\
\hline
\end{tabular}

muscle is important for recognizing how these changes contribute to the disability of stroke. Results of this study might lead to the development of new pharmacological or intervention strategies that improve muscle structure and metabolic function in stroke survivors.

Several major gene categories or clusters are differentially expressed between the paretic and nonparetic leg muscles, including genes that regulate muscle metabolism, contractile proteins, cell cycle progression, mitogenesis and growth factors, metabolism, inflammation, and sig-

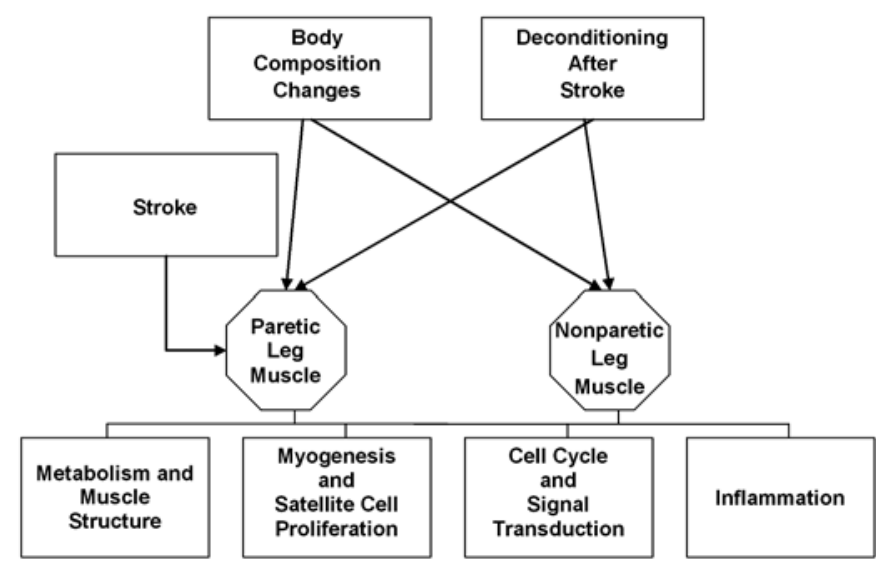

Figure 1.

Proposed influences of stroke on skeletal muscle and possible gene clusters induced by these muscle changes. nal transduction pathways. Figure 2 shows the number of genes reported as significantly altered in each gene cluster and whether expression was higher in the paretic or nonparetic limb. Metabolism is one of the major gene clusters altered in the paretic leg muscle after stroke. Generally, slow-twitch muscle fibers have greater oxidative metabolism and fast-twitch fibers have greater glycolytic metabolism. In the current study, two oxidative enzyme genes were significantly down-regulated in the paretic leg. These oxidative genes are 3-oxoacid coenzyme A transferase 1 (OXCT1) and 3-hydroxybutyrate dehydrogenase, type 1 (BDH1) [20]. In addition, transcript

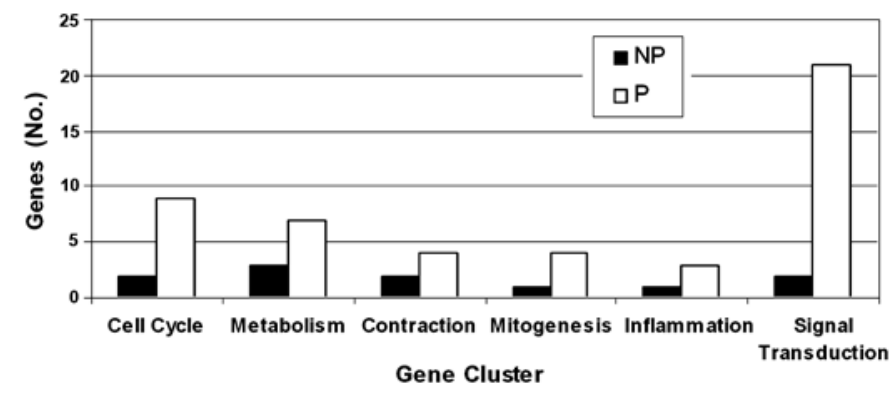

Figure 2.

Genes reported as significantly changed, shown grouped by cluster. Genes in nonparetic (NP) bars had lower expression in paretic (P) than NP vastus lateralis (VL) muscle, while genes in P bars had higher expression in $\mathrm{P}$ than NP VL muscle. 
levels for glycerol-3-phosphate dehydrogenase 2 (GPD2), which is integral to muscle glycolysis, are significantly elevated in the paretic compared with the nonparetic leg. These findings are consistent with evidence based on muscle MHC isoform profiles that show that paretic leg skeletal muscle shifts to fast-twitch muscle fibers with increased reliance on anaerobic metabolism during singleleg exercise after stroke [3,12]. Prior muscle biology studies have demonstrated plasticity of muscle fiber composition and enzymatic activity that depend on the specific task requirements of individual muscles [21]; physical activity level [22]; and stimulus applied to the muscle, such as electrical stimulation [20]. Future studies should assess whether exercise or other rehabilitation strategies can modify these changes in gene expression in the hemiparetic leg muscle.

Changes in muscle contractile protein gene expression could have great consequences for muscle performance after stroke. Gross muscular atrophy predicts reduced cardiovascular fitness levels after stroke [23]. The shift to a fast MHC isoform in the hemiparetic leg is inversely related to a neurological deficit indexed by walking speed; individuals with the greatest shift in fast MHC isoforms had the slowest gait speeds [3]. Physical inactivity or detraining and muscle unloading have been previously reported to lead to a fiber type transition from slow oxidative to fast nonoxidative fibers [24-26]. In a nondisabled untrained person, the VL muscle is composed of various MHC isoforms: approximately 40 percent MHC I, 40 percent MHC IIa, and 20 percent MHC IIx muscle fibers. Chronic stroke produces more profound shifts in the fast MHC profile in skeletal muscle with 65 percent fast MHC fibers [3]. The current study found significant upregulation of embryonic myosin heavy polypeptide (MYH) isoform genes in the paretic leg. The MYH3 and MYH8 genes are up-regulated in the paretic leg 4.3-fold and 3.7-fold, respectively. Gene expression changes for other muscle contractile proteins, as well. Myosin regulatory light chains regulate the kinetics of force transmission of the specific MHC isoforms by modulating the binding of fast and slow myosin light chain (MLC) isoforms [27-28]. In the current study, the MRLC3 and myosin light polypeptide 6B (MYL6B) genes were significantly down-regulated in the paretic leg after chronic stroke. Clearly, stroke leads to changes in gene expression for muscle contractile proteins, as evidenced by our MYH and MLC gene alterations. The factors regulating these changes in gene expression and the func- tional consequences are not known. MHC and MLC profiles can be altered by physical activity. In nondisabled volunteers, training can shift MHC to a slow profile with 60 percent MHC I, 30 percent MHC IIa, and 10 percent MHC IIx muscle fibers [29]. Similarly, functional electrical stimulation can shift the fast MHC isoform profile from SCI to a slow MHC profile [16,30]. Our laboratory is currently investigating whether an exercise intervention can reverse these MHC and MLC gene profiles in the paretic leg muscle after stroke.

We found that a number of genes that regulate myogenesis and satellite cell activation are altered in the paretic leg muscle after stroke. Upon muscle injury, satellite cells reenter the cell cycle, proliferate, and exit the cell cycle to differentiate into mature muscle fibers or proliferate to restore the satellite cell population [31-32]. Proliferating cells leave the cell cycle arrest $\left(\mathrm{G}_{0}\right.$ or resting) phase and enter the cell cycle at the Gap $1\left(G_{1}\right)$ to Synthesis (S) phases through activation of the cyclindependent kinases signaling pathway. Muscle cell proliferation and differentiation are controlled through a series of myogenic regulatory factors. Consistent with these observations, we show that the paretic leg has increased gene expression of cyclin-dependent kinase inhibitor $1 \mathrm{~A}$ (CDKN1A), which blocks progression from the $\mathrm{G}_{1}$ to $\mathrm{S}$ phase. Growth arrest and DNA-damage-inducible 45 alpha (GADD45a), which is implicated in cell cycle arrest, apoptosis, and DNA repair [33], is upregulated in the paretic leg after stroke. We found that mammalian homologues of DNA mismatch repair (MSH3) genes are down-regulated in the paretic leg. Alterations of this gene are thought to contribute to cancer progression [34]. The paretic leg expressed increased gene levels of epidermal growth factor receptor (ERBB3), a tyrosine kinase that plays a critical role in the regulation of embryonic muscle development [35]. Additionally, myogenin, a gene involved in mature myofibril differentiation, exhibits elevated expression in the paretic leg. Platelet-derived growth factor C (PDGF-C) gene expression also is increased in the paretic compared with nonparetic leg in this study. This growth factor is often expressed in the myoblasts before they fuse into myotubes in developing embryonic muscle but not in adult skeletal muscle [36]. Altered signal transduction pathways and nuclear transcription regulation genes have previously been reported in the brain in neurodegeneration and after brain injuries [37-38]. Our present skeletal muscle study is in agreement, because several genes known to play a role in signal transduction or nuclear 
transcription were reported as significantly altered. An understanding of the molecular regulation of satellite cell activation and myocyte differentiation after stroke could lead to development of new interventions that target satellite cells and thus improve muscle structure and performance after stroke.

Finally, a number of inflammatory genes were altered in chronic stroke muscle. We previously reported that TNF- $\alpha$ levels were significantly elevated in the VL muscles of the paretic compared with the nonparetic leg after stroke [14]. In the present study, we report elevated gene expression of a disintegrin and metalloprotease ( $A D A M)$ in the paretic leg muscle after stroke. ADAM proteins are important regulators of cellular adhesion and recognition, because they combine regulated proteolysis with modulation of cell adhesion to guide remodeling of the extracellular matrix along the migratory path [39]. In contrast, interleukin-17D, an inflammatory cytokine, is actually lower in the paretic leg than the nonparetic leg. On the basis of our study results, stroke appears to indeed activate specific inflammatory pathways and markers in the paretic leg. How these pathways interact and whether pharmaceuticals known to alter inflammatory cascades could limit inflammation remain to be elucidated.

The gene abnormalities noted between the paretic and nonparetic leg muscles in this study are likely secondary to altered neural innervation of muscle and disuse. Findings from this study are consistent with gene and protein changes after SCI. SCI causes a shift to a fast MHC isoform profile and a shift from oxidative to glycolytic muscle metabolism, similar to the skeletal muscle phenotype change after stroke [16,40-43]. The level of contribution from alterations in the neural activation pattern and from deconditioning remains to be elucidated. SCI results in an increased incidence of insulin resistance and diabetes, similar to the high prevalence of these conditions after stroke [5,7,44-45]. These results suggest that paresis resulting from an upper motor neuron lesion of stroke and a spinal cord lesion both induce similar changes in paretic muscles. In other Affymetrix studies probing global gene expression in skeletal muscle, common themes of altered gene expression occurred. Muscle unloading, sarcopenia of aging, and SCI result in upregulation of genes involved in the ubiquitin proteasome pathway and metallothione function [46-48]. In addition, muscle from older individuals have lower levels of genes encoding proteins that are involved in energy metabolism and mitochondrial protein synthesis compared with younger individuals. Skeletal muscle from older individuals also has elevated levels of genes involved in stress responses; hormone, cytokine, and growth factor signaling; cell cycle and apoptosis; and transcriptional regulation, consistent with dedifferentiation [44,48-49]. The $\beta$-adrenergic receptor agonists induce skeletal muscle hypertrophy and induce a different set of gene families. They induce genes associated with myocyte proliferation, myogenic differentiation, and/or recruitment of satellite cells into muscle fibers and genes involved in the initiation of translation to increase protein synthesis through upregulation of translational initiators [50-51]. Results from this study suggest that stroke induces changes in gene expression that parallel those in SCI, aging, and disuse but also have divergent gene family alteration from these other conditions.

Further investigations must confirm the magnitude of these gene changes by real-time reverse transcriptase polymerase chain reaction and determine whether these gene changes also alter protein levels and their activities in these muscles. One should note that stroke survivors likely take a wide variety of prescription medications, including aspirin, beta-blockers, and other antihypertensive and diabetic medications. Statins lower lipid profiles but also have anti-inflammatory benefits. These medications could potentially alter expression of specific genes. However, using each subject as his or her own control enabled us to limit interindividual dietary, medication, and genetic differences and target specific gene differences on the paretic and nonparetic sides. A limitation of this study is that it assumes that the changes in skeletal muscle are restricted to the paretic limb in stroke survivors. It does not account for more systemic changes that could affect gene expression even in the unaffected nonparetic leg muscle. Further studies using age-, disease-, and medication-matched nonstroke subjects are necessary to determine differences that may exist between both the paretic and nonparetic leg muscles and nonstroke control leg muscles. Additionally, stroke causes weakness and spasticity with increased muscular tone, which could both affect the magnitude of gene changes in the muscle. This study was not powered to determine the degree to which spasticity affects gene expression. Collectively, these data describe this population as being severely at risk for health-related detriments. In a patient with stroke, these muscle changes could affect muscle performance characteristics and cardiovascular fitness levels, as well as increase future risk of cardiovascular disease, diabetes, and metabolic syndrome. 
Exercise has been shown to decrease the risk of cardiovascular disease, diabetes, metabolic syndrome, and functional decline [52]. Exercise can shift muscle fibers to a slow MHC phenotype and improve insulin sensitivity. Through insights from these genetic alterations in the paretic compared with the nonparetic leg muscles after stroke, we may develop therapeutic interventions that modify these altered gene expressions. Possible strategies could include pharmaceuticals [50-51], functional electrical stimulation [30,53], and aerobic or resistive exercise training. The beneficial effects of aerobic exercise training have been demonstrated in stroke $[17,54-56]$ and SCI rehabilitation programs [57-60].

\section{ACKNOWLEDGMENTS}

This material was based on work supported in part by the Baltimore Department of Veterans Affairs (VA) Medical Center Geriatric Research, Education, and Clinical Center; the Baltimore VA Exercise and Robotics Center of Excellence (to R. F. Macko); the Baltimore VA Research Enhancement Award Program (to R. F. Macko); the VA Merit Review program (awards to C. E. Hafer-Macko and A. S. Ryan); a VA Research Career Scientist Award (to A. S. Ryan); the University of Maryland Claude D. Pepper Center (grant P30-AG-12583 to A. P. Goldberg); and the National Institutes of Health (grant R01-AG019310 to A. S. Ryan).

The authors have declared that no competing interests exist.

\section{REFERENCES}

1. Gresham GE, Phillips TF, Wolf PA, McNamara PM, Kannel WB, Dawber TR. Epidemiologic profile of long-term stroke disability: The Framingham study. Arch Phys Med Rehabil. 1979;60(11):487-91. [PMID: 508073]

2. Blaak EE. Basic disturbances in skeletal muscle fatty acid metabolism in obesity and type 2 diabetes mellitus. Proc Nutr Soc. 2004;63(2):323-30. [PMID: 15294050]

3. De Deyne PG, Hafer-Macko CE, Ivey FM, Ryan AS, Macko RF. Muscle molecular phenotype after stroke is associated with gait speed. Muscle Nerve. 2004;30(2):209-15. [PMID: 15266637]

4. Ivey FM, Ryan AS, Hafer-Macko CE, Garrity BM, Sorkin JD, Goldberg AP, Macko RF. High prevalence of abnormal glucose metabolism and poor sensitivity of fasting plasma glucose in the chronic phase of stroke. Cerebrovasc Dis. 2006;22(5-6):368-71. [PMID: 16888377]

5. Kernan WN, Inzucchi SE. Type 2 diabetes mellitus and insulin resistance: Stroke prevention and management. Curr Treat Options Neurol. 2004;6(6):443-50. [PMID: 15461922]

6. Roth EJ. Heart disease in patients with stroke: Incidence, impact, and implications for rehabilitation. Part 1: Classification and prevalence. Arch Phys Med Rehabil. 1993;74(7): 752-60. [PMID: 8328899]

7. Vermeer SE, Sandee W, Algra A, Koudstaal PJ, Kappelle LJ, Dippel DW; Dutch TIA Trial Study Group. Impaired glucose tolerance increases stroke risk in nondiabetic patients with transient ischemic attack or minor ischemic stroke. Stroke. 2006;37(6):1413-17. [PMID: 16627787]

8. Gresham GE, Fitzpatrick TE, Wolf PA, McNamara PM, Kannel WB, Dawber TR. Residual disability in survivors of stroke-The Framingham study. N Engl J Med. 1975; 293(19):954-56. [PMID: 1178004]

9. U.S. Department of Health and Human Services. Poststroke rehabilitation: Clinical practice guideline number 16. Rockville (MD): Public Health Service, Agency for Health Care Policy and Research; 1995.

10. Wade DT, Hewer RL. Functional abilities after stroke: Measurement, natural history and prognosis. J Neurol Neurosurg Psychiatry. 1987;50(2):177-82. [PMID: 3572432]

11. Williams GR, Jiang JG, Matchar DB, Samsa GP. Incidence and occurrence of total (first-ever and recurrent) stroke. Stroke. 1999;30(12):2523-28. [PMID: 10582972]

12. Landin S, Hagenfeldt L, Saltin B, Wahren J. Muscle metabolism during exercise in hemiparetic patients. Clin Sci Mol Med. 1977;53(3):257-69. [PMID: 913049]

13. Daugaard JR, Richter EA. Relationship between muscle fibre composition, glucose transporter protein 4 and exercise training: Possible consequences in non-insulin-dependent diabetes mellitus. Acta Physiol Scand. 2001;171(3):267-76. [PMID: 11412139]

14. Hafer-Macko CE, Yu S, Ryan AS, Ivey FM, Macko RF. Elevated tumor necrosis factor-alpha in skeletal muscle after stroke. Stroke. 2005;36(9):2021-23. [PMID: 16109906]

15. Ryan AS, Dobrovolny CL, Smith GV, Silver KH, Macko RF. Hemiparetic muscle atrophy and increased intramuscular fat in stroke patients. Arch Phys Med Rehabil. 2002; 83(12):1703-7. [PMID: 12474173$]$

16. Burnham R, Martin T, Stein R, Bell G, MacLean I, Steadward R. Skeletal muscle fibre type transformation following spinal cord injury. Spinal Cord. 1997;35(2):86-91.

[PMID: 9044514]

17. Macko RF, Ivey FM, Forrester LW, Hanley D, Sorkin JD, Katzel LI, Silver KH, Goldberg AP. Treadmill exercise rehabilitation improves ambulatory function and cardiovascular fitness in patients with chronic stroke: A randomized, 
controlled trial. Stroke. 2005;36(10):2206-11. [PMID: 16151035]

18. Haeuber E, Shaughnessy M, Forrester LW, Coleman KL, Macko RF. Accelerometer monitoring of home- and community-based ambulatory activity after stroke. Arch Phys Med Rehabil. 2004;85(12):1997-2001. [PMID: 15605339$]$

19. Chomczynski P, Sacchi N. Single-step method of RNA isolation by acid guanidinium thiocyanate-phenol-chloroform extraction. Anal Biochem. 1987;162(1):156-59.

[PMID: 2440339]

20. Mayne CN, Sutherland H, Jarvis JC, Gilroy SJ, Craven AJ, Salmons S. Induction of a fast-oxidative phenotype by chronic muscle stimulation: Histochemical and metabolic studies. Am J Physiol. 1996;270(1 Pt 1):C313-20. [PMID: 8772459]

21. Gregory CM, Vandenborne K, Dudley GA. Metabolic enzymes and phenotypic expression among human locomotor muscles. Muscle Nerve. 2001;24(3):387-93.

[PMID: 11353424]

22. Mujika I, Padilla S. Muscular characteristics of detraining in humans. Med Sci Sports Exerc. 2001;33(8):1297-1303. [PMID: 11474330]

23. Ryan AS, Dobrovolny CL, Smith GV, Silver KH, Macko RF. Cardiovascular fitness after stroke: Role of muscle mass and gait deficit severity. J Stroke Cerebrovasc Dis. 2000;9:1-8.

24. Pette D, Staron RS. Myosin isoforms, muscle fiber types, and transitions. Microsc Res Tech. 2000;50(6):500-509. [PMID: 10998639]

25. Serrano AL, Quiroz-Rothe E, Rivero JL. Early and longterm changes of equine skeletal muscle in response to endurance training and detraining. Pflugers Arch. 2000; 441(2-3):263-74. [PMID: 11211112]

26. Talmadge RJ. Myosin heavy chain isoform expression following reduced neuromuscular activity: Potential regulatory mechanisms. Muscle Nerve. 2000;23(5):661-79. [PMID: 10797389]

27. Andruchov O, Andruchova O, Wang Y, Galler S. Dependence of cross-bridge kinetics on myosin light chain isoforms in rabbit and rat skeletal muscle fibres. J Physiol. 2006;571(Pt 1):231-42. [PMID: 16357018]

28. Gonzalez B, Negredo P, Hernando R, Manso R. Protein variants of skeletal muscle regulatory myosin light chain isoforms: Prevalence in mammals, generation and transitions during muscle remodeling. Pflugers Arch. 2002;443(3): 377-86. [PMID: 11810206]

29. Zawadowska B, Majerczak J, Semik D, Karasinski J, Kolodziejski L, Kilarski WM, Duda K, Zoladz JA. Characteristics of myosin profile in human vastus lateralis muscle in relation to training background. Folia Histochem Cytobiol. 2004;42(3):181-90. [PMID: 15493580]
30. Shields RK, Dudley-Javoroski S. Musculoskeletal plasticity after acute spinal cord injury: Effects of long-term neuromuscular electrical stimulation training. J Neurophysiol. 2006;95(4):2380-90. [PMID: 16407424]

31. Collins CA, Partridge TA. Self-renewal of the adult skeletal muscle satellite cell. Cell Cycle. 2005;4(10):1338-41. [PMID: 16177569]

32. Grounds MD, Yablonka-Reuveni Z. Molecular and cell biology of skeletal muscle regeneration. Mol Cell Biol Hum Dis Ser. 1993;3:210-56. [PMID: 8111541]

33. Fornace AJ Jr, Nebert DW, Hollander MC, Luethy JD, Papathanasiou M, Fargnoli J, Holbrook NJ. Mammalian genes coordinately regulated by growth arrest signals and DNAdamaging agents. Mol Cell Biol. 1989;9(10):4196-4203. [PMID: 2573827]

34. Kolodner R. Biochemistry and genetics of eukaryotic mismatch repair. Genes Dev. 1996;10(12):1433-42. [PMID: 8666228$]$

35. Kraus MH, Issing W, Miki T, Popescu NC, Aaronson SA. Isolation and characterization of ERBB3, a third member of the ERBB/epidermal growth factor receptor family: Evidence for overexpression in a subset of human mammary tumors. Proc Natl Acad Sci U S A. 1989;86(23):9193-97. [PMID: 2687875]

36. Tallquist MD, Weismann KE, Hellstrom M, Soriano P. Early myotome specification regulates PDGFA expression and axial skeleton development. Development. 2000;127(23): 5059-70. [PMID: 11060232]

37. Bazan NG, Marcheselli VL, Cole-Edwards K. Brain response to injury and neurodegeneration: Endogenous neuroprotective signaling. Ann N Y Acad Sci. 2005;1053: 137-47. [PMID: 16179516]

38. Hara MR, Snyder SH. Cell signaling and neuronal death. Annu Rev Pharmacol Toxicol. 2007;47:117-41. [PMID: 16879082]

39. Blobel CP. Metalloprotease-disintegrins: Links to cell adhesion and cleavage of TNF alpha and notch. Cell. 1997; 90(4):589-92. [PMID: 9288739]

40. Baldwin KM, Herrick RE, McCue SA. Substrate oxidation capacity in rodent skeletal muscle: Effects of exposure to zero gravity. J Appl Physiol. 1993;75(6):2466-70. [PMID: 8125864]

41. Dupont-Versteegden EE, Houle JD, Gurley M, Peterson CA. Early changes in muscle fiber size and gene expression in response to spinal cord transection and exercise. Am J Physiol. 1998;275(4 Pt 1):C1124-33. [PMID: 9755066]

42. Hutchinson KJ, Linderman JK, Basso DM. Skeletal muscle adaptations following spinal cord contusion injury in rat and the relationship to locomotor function: A time course study. J Neurotrauma. 2001;18(10):1075-89.

[PMID: 11686494] 
43. Stein TP, Wade CE. Metabolic consequences of muscle disuse atrophy. J Nutr. 2005;135(7):1824S-28. [PMID: 15987873]

44. Bauman WA, Spungen AM. Metabolic changes in persons after spinal cord injury. Phys Med Rehabil Clin N Am. 2000;11(1):109-40. [PMID: 10680161]

45. Elder CP, Apple DF, Bickel CS, Meyer RA, Dudley GA. Intramuscular fat and glucose tolerance after spinal cord injury-A cross-sectional study. Spinal Cord. 2004;42(12): 711-16. [PMID: 15303112]

46. Urso ML, Chen YW, Scrimgerour AG, Lee PC, Lee KF, Clarkson PM. Alterations in mRNA expression and protein products following spinal cord injury in humans. J Appl Physiol. 2007;579(Pt 3):877-92. [PMID: 17218363]

47. Urso ML, Scrimgeour AG, Chen YW, Thompson PD, Clarkson PM. Analysis of human skeletal muscle after $48 \mathrm{~h}$ immobilization reveals alterations in mRNA and protein for extracellular matrix components. J Appl Physiol. 2006; 101(4):1136-48. [PMID: 16763108]

48. Welle S, Brooks AI, Delehanty JM, Needler N, Thornton CA. Gene expression profile of aging in human muscle. Physiol Genomics. 2003;14(2):149-59. [PMID: 12783983]

49. Jozsi AC, Dupont-Versteegden EE, Taylor-Jones JM, Evans WJ, Trappe TA, Campbell WW, Peterson CA. Aged human muscle demonstrates an altered gene expression profile consistent with an impaired response to exercise. Mech Ageing Dev. 2000;120(1-3):45-56. [PMID: 11087903]

50. Signorile JF, Banovac K, Gomez M, Flipse D, Caruso JF, Lowensteyn I. Increased muscle strength in paralyzed patients after spinal cord injury: Effect of beta-2 adrenergic agonist. Arch Phys Med Rehabil. 1995;76(1):55-58. [PMID: 7811176]

51. Spurlock DM, McDaneld TG, McIntyre LM. Changes in skeletal muscle gene expression following clenbuterol administration. BMC Genomics. 2006;7:320. [PMID: 17181869]

52. Whaley $\mathrm{MH}$, Brubaker $\mathrm{PH}$, Otto RM, Armstrong LE. ACSM's guidelines for exercise testing and prescription. 7th ed. Philadelphia (PA): Lippincott Williams \& Wilkins; 2006. p. xxi, 366.

53. Shields RK, Dudley-Javoroski S, Littmann AE. Postfatigue potentiation of the paralyzed soleus muscle: Evidence for adaptation with long-term electrical stimulation training. J Appl Physiol. 2006;101(2):556-65. [PMID: 16575026]

54. Ivey FM, Macko RF, Ryan AS, Hafer-Macko CE. Cardiovascular health and fitness after stroke. Top Stroke Rehabil. 2005;12(1):1-16. [PMID: 15735997]

55. Macko RF, Ivey FM, Forrester LW. Task-oriented aerobic exercise in chronic hemiparetic stroke: Training protocols and treatment effects. Top Stroke Rehabil. 2005;12(1):45-57. [PMID: 15736000]

56. Macko RF, Smith GV, Dobrovolny CL, Sorkin JD, Goldberg AP, Silver KH. Treadmill training improves fitness reserve in chronic stroke patients. Arch Phys Med Rehabil. 2001;82(7):879-84. [PMID: 11441372]

57. Gerrits HL, Hopman MT, Offringa C, Engelen BG, Sargeant AJ, Jones DA, Haan A. Variability in fibre properties in paralysed human quadriceps muscles and effects of training. Pflugers Arch. 2003;445(6):734-40. [PMID: 12632195]

58. Kjaer M, Mohr T, Biering-Sorensen F, Bangsbo J. Muscle enzyme adaptation to training and tapering-off in spinalcord-injured humans. Eur J Appl Physiol. 2001;84(5):482-86. [PMID: 11417439]

59. Phillips SM, Stewart BG, Mahoney DJ, Hicks AL, McCartney N, Tang JE, Wilkinson SB, Armstrong D, Tarnopolsky MA. Body-weight-support treadmill training improves blood glucose regulation in persons with incomplete spinal cord injury. J Appl Physiol. 2004;97(2):716-24.

[PMID: 15107410]

60. Stewart BG, Tarnopolsky MA, Hicks AL, McCartney N, Mahoney DJ, Staron RS, Phillips SM. Treadmill traininginduced adaptations in muscle phenotype in persons with incomplete spinal cord injury. Muscle Nerve. 2004;30(1): 61-68. [PMID: 15221880]

Submitted for publication February 15, 2007. Accepted in revised form July 24, 2007. 